\title{
EFFECT OF BIOSTIMULANT BASED ON STRAW COMPOST AND N,P,K FERTILIZER ON POPULATION OF AZOSPIRILLUM SP., N-TOTAL, AND RED CHILI FRUITSET (Capsicum annum L.) IN SALINE SOIL
}

\author{
Ibnu Rizki Perdana, Mieke Rochimi Setiawati and Pudjawati Suryatmana \\ Soil Science Department, Agriculture Faculty of Universitas Padjadjaran \\ Jl. Raya Bandung Sumedang Km 21 Jatinangor Kab. Sumedang 45363, Indonesia
}

https://doi.org/10.35410/IJAEB.2021.5657

\begin{abstract}
Salinity due to abiotic stress can reduce yields and productivity of agricultural crops. The purpose of this study was to determine the effect of biostimulant application based on straw compost and N,P,K fertilizer in increasing saline soil fertility and yield of red chili (Capsicum annum L.). This study used Randomized Block Design (RBD) with treatment a control, as well as a combination of rice straw compost without and plus biostimulants with reduced doses of $\mathrm{N}, \mathrm{P}, \mathrm{K}$ fertilizer on $0 \mathrm{dS} / \mathrm{m}$ and $4 \mathrm{dS} / \mathrm{m}$ soil. The results showed that the best population of Azospirillum sp. in $0 \mathrm{dS} / \mathrm{m}$ was found in the straw compost plus + fertilizer $\mathrm{N}, \mathrm{P}, \mathrm{K}$ recommended dose with a population of $(16.32 \times 108 \mathrm{CFUg}-1)$, and $(4 \mathrm{dS} / \mathrm{m})$ it was found in thestraw compost +1 dose of N,P,K fertilizer (13.91 x 108 CFUg-1). N-total soil gave no significant effect on both of soils, however straw compost plus +1 fertilizer $\mathrm{N}, \mathrm{P}, \mathrm{K}$ at the recommended dose $(4 \mathrm{dS} / \mathrm{m})$ tends to increase compared to the initial soil analysis which contains only $(0.18 \%)$. Straw compost plus +1 recommended dose of N,P,K fertilizer $(0 \mathrm{dS} / \mathrm{m})$ can maintain flowers with the highest percentage of fruit set $(90.86 \%)$.
\end{abstract}

Keywords: Azospirillum, Biostimulant, Combination Fertilizer, Red Chili, Rice Straw Compost, Salinity.

\section{INTRODUCTION}

Saline soil is soil that has a very high salt content and is dominated by salts such as $\mathrm{NaCl}$, $\mathrm{NaSO} 4, \mathrm{CaCl} 2, \mathrm{MgSO} 4, \mathrm{MgCl} 2$ which causes low availability of $\mathrm{N}, \mathrm{P}, \mathrm{Mn}, \mathrm{Cu}, \mathrm{Zn}$, and $\mathrm{Fe}$ in the soil (Munns, and Tester, 2008), with EC value $4 \mathrm{dS} / \mathrm{m}, \mathrm{pH}<8.5$, and $\mathrm{Na}$-dd $<15 \%$ (USDA, 2010), resulting in high osmotic pressure, weak movement of water and air, inhibition of soil microbial activity, and damage to the physical, chemical and biological properties of the soil. (Zahran et al, 1995; Gamalero et al, 2009).

Several attempts have been made to increase soil fertility, such as the use of saline tolerant varieties, adding inputs to environmental engineering technology using PGPR (Plant Growth Promoting Rhizobacteria) which can improve salinity, and increase plant growth(Lugtenberg and Kamilova 2009; Pliego et al, 2011). Rice straw compost is known to increase the moisture holding capacity, maintain pore space and accelerate the dilution of salt concentrations in the soil solution (Abdel-Fattah, 2012). Rice straw compost enriched with Plant Growth Promoting 
Vol. 06, No. 04; 2021

ISSN: $2456-8643$

Rhizobacteria (PGPR) microbes is known to be used as a biostimulant that can increase nutrient availability and plant growth (Ahmad et al, 2008).

Azospirillum sp. is one type of Nitrogen-fixing Bacteria which is known to be able to fix free nitrogen in the atmosphere into $\mathrm{NH} 4+$ by producing nitrogenase enzymes consisting of $\mathrm{Fe}$ and MoFe proteins, so as to increase the supply of $\mathrm{N}$ available to plants. Research resultsGharib et al. (2008) that the addition of compost can increase the population of N2-fixing rhizobacteria, reduce the use of urea, improve soil health and crop yields.Azospirillum sp. can increase the Ntotal content of the soil through the process of mineralization of organic matter by producing biotin which plays a role in catalyzing carbohydrates, proteins, and fats in cell growth (Bonjour, 1991; Indriani et al, 2017).Azospirillum sp. is also able to produce IAA which is useful in stimulating the growth and production of root exudates(Lestari et al., 2007).

The planting of horticultural commodities using straw compost and biostimulant microbes in saline soil has not been done much. Based on this, it is expected that the application of a combination of straw compost with microbial biostimulants and doses of N, P, K fertilizers can increase soil fertility and optimize the growth and yield of red chili (Capsicum annum L.) on the saline Inceptisol soil.

\section{MATERIALS AND METHODS}

This research was conducted at the Soil Biology Laboratory, the Laboratory of Soil Fertility and Plant Nutrition, and the Greenhouse Experimental Garden, Faculty of Agriculture, UniversitasPadjadjaran. This research was conducted from January-April 2021.

The tools used in this research are: test tube and its rack, volume pipette, tip, tube, sprayer, erlenmeyer, beaker glass, petri dish, micro pipette, bunsen lamp, ose needle, spatula, tweezers, glass preparation, aluminum foil, rubber band, plastic wrap, autoclave, microscope, Laminar Air Flow (LAF), incubator, refrigerator, oven, $100 \mathrm{~mL}$ test tube, magnifying glass, vortex stirrer, ruler, analytical balance three decimal accuracy, camera, stationery, and shaker, $15 \mathrm{ml}$ injection, $10 \mathrm{~kg}$ capacity polybag, digital soil thermometer, moisture soil meter, $\mathrm{pH}$ meter, EC meter, scope, seedling tray, inorganic fertilizer (Urea, KCl, SP-36), shaker bottle, wrap (6) chemicals for TPC calculation (Total plate count) namely distilled water, physiological $\mathrm{NaCl}$ (7) isolation culture media: liquid Ashbys media, liquid Okon, liquid Pikovskaya, liquid TSB, Isolates of the Microbial Consortium (Azotobacter sp., Azospirillum sp., PSB, saline-resistant endophytic bacteria) , (8) Rice Straw Compost, and (9) Technical $\mathrm{NaCl}$ with a salt concentration of $99 \%$.

This study used an experimental method in the form of a Randomized Block Design (RBD) consisting of 14 treatment combinations. The treatment consists of without straw compost without adding salt $(0 \mathrm{dS} / \mathrm{m})$ and a combination of rice straw compost without or added biostimulant (straw compost plus) with a reduced dose of N,P,K fertilizer without and added salt $(4 \mathrm{dS} / \mathrm{m})$. Each treatment was repeated three times so that there were 42 experimental units. The data obtained were then analyzed for variance with the $\mathrm{F}$ test at a 5\% significance level. If the calculated $\mathrm{F}$ value $>\mathrm{F}$ table 5\%, Duncan's further test (DMRT) will be carried out at a 5\% significance level to determine the difference in the average value between treatments. 
Vol. 06, No. 04; 2021

ISSN: $2456-8643$

Table 1. Combination of Straw Compost DosageTreatment + N, P, K doseand soil salinity level in red chili (Capsicum annum L.)

\begin{tabular}{|c|c|c|c|c|c|c|}
\hline \multirow[t]{2}{*}{ Code } & \multirow[t]{2}{*}{ Treatment } & \multirow{2}{*}{$\begin{array}{l}\text { Biostimulant } \\
\text { Dosage } \\
\left(\mathrm{mL} \cdot \mathrm{L}^{-1}\right)\end{array}$} & \multirow{2}{*}{$\begin{array}{c}\text { Straw } \\
\text { Compost } \\
\text { Dosage (per } \\
\text { polybag) }\end{array}$} & \multicolumn{3}{|c|}{$\begin{array}{c}\text { Single Dose of } \\
\text { Inorganic Fertilizer } \\
\left(\mathrm{kg} \cdot \mathrm{ha}^{-1}\right)\end{array}$} \\
\hline & & & & Urea & SP-36 & $\mathrm{KCl}$ \\
\hline $\mathbf{A}$ & Control (0 dS/m) & 0 & 0 & 0 & 0 & 0 \\
\hline $\mathbf{B}$ & $\begin{array}{l}\text { Compost Straw }+1 \text { fertilizer } \mathrm{N}, \mathrm{P} \text {, } \\
\mathrm{K} \text { recommended dose }(0 \mathrm{dS} / \mathrm{m})\end{array}$ & 0 & $50 \mathrm{~g}$ & 300 & 300 & 250 \\
\hline C & $\begin{array}{l}\text { Compost Straw }+3 / 4 \text { fertilizer } N, P \text {, } \\
\text { K recommended dose }(0 \mathrm{dS} / \mathrm{m})\end{array}$ & 0 & $50 \mathrm{~g}$ & 225 & 225 & $\begin{array}{c}187 . \\
5\end{array}$ \\
\hline D & $\begin{array}{l}\text { Compost Straw }+1 / 2 \text { fertilizer } N, P \text {, } \\
\text { K recommended dose }(0 \mathrm{dS} / \mathrm{m})\end{array}$ & 0 & $50 \mathrm{~g}$ & 150 & 150 & 125 \\
\hline $\mathbf{E}$ & $\begin{array}{l}\text { Compost Straw Plus }+1 \text { fertilizer } \\
\text { N,P,K recommended dose }(0 \mathrm{dS} / \mathrm{m})\end{array}$ & 3.75 & $50 \mathrm{~g}$ & 300 & 300 & 250 \\
\hline $\mathbf{F}$ & $\begin{array}{l}\text { Compost Straw Plus }+3 / 4 \text { fertilizer } \\
\text { N,P,K recommended dose }(0 \mathrm{dS} / \mathrm{m})\end{array}$ & 3.75 & $50 \mathrm{~g}$ & 225 & 225 & $\begin{array}{c}187 . \\
5\end{array}$ \\
\hline $\mathbf{G}$ & $\begin{array}{l}\text { Compost Straw Plus }+1 / 2 \text { fertilizer } \\
\text { N,P,K recommended dose }(0 \mathrm{dS} / \mathrm{m})\end{array}$ & 3.75 & $50 \mathrm{~g}$ & 150 & 150 & 125 \\
\hline $\mathbf{H}$ & Control (4 dS/m) & 0 & 0 & 0 & 0 & 0 \\
\hline $\mathbf{I}$ & $\begin{array}{l}\text { Compost Straw }+1 \text { fertilizer N, P, } \\
\text { K recommended dose }(4 \mathrm{dS} / \mathrm{m})\end{array}$ & 0 & $50 \mathrm{~g}$ & 300 & 300 & 250 \\
\hline $\mathbf{J}$ & $\begin{array}{l}\text { Compost Straw }+3 / 4 \text { fertilizer } N, P \text {, } \\
\text { K recommended dose }(4 \mathrm{dS} / \mathrm{m})\end{array}$ & 0 & $50 \mathrm{~g}$ & 225 & 225 & $\begin{array}{c}187 . \\
5\end{array}$ \\
\hline $\mathbf{K}$ & $\begin{array}{l}\text { Compost Straw }+1 / 2 \text { fertilizer } N, P \text {, } \\
\text { K recommended dose }(4 \mathrm{dS} / \mathrm{m})\end{array}$ & 0 & $50 \mathrm{~g}$ & 150 & 150 & 125 \\
\hline $\mathbf{L}$ & $\begin{array}{l}\text { Compost Straw Plus }+1 \text { fertilizer } \\
\text { N, P, K recommended dose }(4 \\
\text { dS } / \mathrm{m})\end{array}$ & 3.75 & $50 \mathrm{~g}$ & 300 & 300 & 250 \\
\hline
\end{tabular}


International Journal of Agriculture, Environment and Bioresearch

Vol. 06, No. 04; 2021

ISSN: $2456-8643$

M Compost Straw Plus $+3 / 4$ fertilizer

3.75

$50 \mathrm{~g}$

225

225

187.

$\mathrm{N}, \mathrm{P}, \mathrm{K}$ recommended dose (4

$\mathrm{dS} / \mathrm{m})$

$\mathbf{N}$

Compost Straw Plus $+1 / 2$ fertilizer

3.75

$50 \mathrm{~g}$

150

150

125

N, P, K recommended dose (4

$\mathrm{dS} / \mathrm{m})$

The implementation of the research began with producing biostimulants which were the result of isolation, selection, and characterization of previous studies, (the source of the isolates came from termites' nest microbes which later became the collection of the Soil Biology Lab, Faperta Unpad). The isolates of the microbial consortium were prepared by rejuvenating the isolates in pure culture by scratching the isolates into a slanted agar using an aseptic needle. The results of the rejuvenation of the isolates were then incubated in an incubator at $28 \mathrm{oC}$ for 3 days.

The refreshed microbes were then inoculated into liquid selective media: Azotobacter sp. (liquid Ashbys medium), Azospirillum sp. (liquid Okon media), Phosphate Solubilizing Bacteria (PSB) (liquid Pikovskaya media).Starter that has been prepared in liquid selective media is then inoculated as much as 5\% for each type of microbe in $3 \%$ molasses, which is used as a microbial consortium to inoculate $2.5 \%$ of the total requirement of straw compost used during the study. Furthermore, the biostimulant inoculated straw compost was tested for viability by counting the microbial population every $2 \times 24$ hours. Soil analysis and initial rice straw compost need to be carried out to determine the physical, chemical, and biological properties before being given treatment.

The soil order used for this research was Inceptisol Jatinangor taken from the Ciparanje experimental garden, which had previously been filtered on a $2 \mathrm{~mm}$ sieve, then weighed and put into polybags measuring $20 \mathrm{~cm}$ long and $40 \mathrm{~cm}$ wide with a height of $\pm 25 \mathrm{~cm}$ for $10 \mathrm{~kg} / \mathrm{polybag}$ on a soil scale, with a total soil requirement of about $10 \mathrm{~kg} /$ poybag x 42 units $=420 \mathrm{~kg}$. Soil sampling was carried out in a composite manner at five sample points using a hoe with a diagonal sampling method at a depth of $0-20 \mathrm{~cm}$ from the soil surface. The soil was cleaned of plant residues and other impurities and air-dried for one day, then analyzed the chemical properties of the soil ( $\mathrm{pH}, \mathrm{C}$-organic, N-total, P-available, K-available, CEC, Base saturation) , textures and microbial population. on the ground. The need for soil samples used for analysis is $500 \mathrm{~g}$ each.

Each polybag that has been filled with soil is then added with technical $\mathrm{NaCl}$ by first dissolving it in $2 \mathrm{gL}-1(\mathrm{EC}=4 \mathrm{dS} / \mathrm{m})$ water which is homogenized manually by hand to be incubated for one day before the straw compost application is carried out. The soil that has been weighed and copied is then added with straw compost treatment according to the recommended dose of red chili plants, which is 10 tonha- 1 and incubated for one week so that the $\mathrm{C} / \mathrm{N}$ of straw compost 
Vol. 06, No. 04; 2021

ISSN: $2456-8643$

can be stable so that microbes and plants can still exist when planted in high salt soil. . The total requirement for technical $\mathrm{NaCl}$ salt in this study was $2 \mathrm{~g} / \mathrm{L} /$ polybag x $36=72 \mathrm{~g}$.

The determination of the technical $\mathrm{NaCl}$ concentration of $2 \mathrm{gL}-1$ (EC $4 \mathrm{dS} / \mathrm{m})$ was determined based on the linear curve equation from the soil EC analysis using the Kadam (2016) method by adding several doses of technical $\mathrm{NaCl}(0.05 \mathrm{~g}, 0.01 \mathrm{~g}, 0.015 \mathrm{~g}, 00.02 \mathrm{~g}, 0.025 \mathrm{~g}, 0.03 \mathrm{~g})$ in $10 \mathrm{~mL}$ of water put in a shaker bottle and then $10 \mathrm{~g}$ of soil $(1: 1)$ was added to analyze the EC value of the soil. The solution was shaken using a shaker at $120 \mathrm{rpm}$ for 30 minutes. The solution was allowed to settle and then the soil EC was measured using an EC meter.

Planting media that are ready are then sampled using a soil sampler at three sampling points around the root area of chili plants homogeneously to observe the microbial population at the time of transplanting (early vegetative) and at the end (maximum nutrient absorption) in each treatment. Preparation of nursery media composition consisting of soil and compost with a ratio of 1: 1 which came from experimental garden land, Faculty of Agriculture Unpad, Ciparanje, Jatinangor-West Java. Soil and compost are mixed using a shovel in a tray measuring $50 \mathrm{x} 40 \mathrm{x}$ $25 \mathrm{~cm}$. The mixed media is put into a seedtray as much as of its volume which is then doused with water until it is moist.The red chili variety used in this study is the Nirwana variety (Unpad CB-2) which is known to be a chili variety that has early maturity with high yield potential and adaptability with fruit yields per hektare of 14.6-23.6 tonha-1. Previously owned red chili seeds were soaked in warm water for 30 minutes to break dormancy and stimulate growth hormone. Chili seed nursery is done by spreading the seeds evenly on the soil surface of the nursery media. The chili plant seeds used in this study were grown for 4 weeks (30 days) on nursery media with chili seed size of about $\pm 10 \mathrm{~cm}$. The chili nursery was carried out with care including watering and weeding to transplanting.

Chili seeds that are 4 MSS are transplanted as much as 1 seed (single seedling) for each polybag with a distance of $75 \mathrm{~cm} \times 50 \mathrm{~cm}$ between seedlings. The application of straw compost and $\mathrm{N}, \mathrm{P}, \mathrm{K}$ fertilizer was carried out according to the treatment, namely the recommended dose of urea (1.5 g/polybag), SP-36 (1.5 g/polybag), $\mathrm{KCl}(1.25 \mathrm{~g} / \mathrm{polybag})$, recommended dose of urea (0.75 g/polybag) SP-36 (0.75 g/polybag), $\mathrm{KCl}(0.625 \mathrm{~g} /$ polybag $)$, and recommended dose of urea (1.125 g/polybag) SP-36 (1.125 g/polybag) $\mathrm{KCl}(0.9375 \mathrm{~g} / \mathrm{polybag})$, so the total need for urea is $6 \times 2 \times 3 \times 3,375=121.5 \mathrm{~g}, \mathrm{SP}-366 \times 2 \times 3 \times 3,375=121.5 \mathrm{~g}$, and $\mathrm{KCl}$ is $6 \times 2 \times 3 \times 2.9375 \mathrm{~g}=105.75 \mathrm{~g}$ previouslyapplied compost treatment a week before transplanting according to the recommended dose of 10 tonha- 1 . Urea fertilization was carried out twice according to the treatment, namely when the plant was 28 DAP (Day After Planting) and 42 DAP (Day After Planting), so that the $\mathrm{N}, \mathrm{P}, \mathrm{K}$ fertilizer was divided into two for each treatment. The recommended doses for chili cultivation are generally $300 \mathrm{~kg}$ ha-1 Urea, $300 \mathrm{~kg}$ ha- $1 \mathrm{SP}-36$, and $250 \mathrm{~kg}$ ha-1 KCl.

Maintenance of chili plants includes watering activities that are carried out every two days according to the amount of water shortage needed by plants at field capacity/day. Calculation of field capacity was carried out by calculating the difference between the final and initial soil weight after adding water to the first drip of water from the polybag during $2 \times 24$ hour incubation. Watering time is done in the morning or evening. Watering was done manually using a measuring cup. 
Weeding is done manually by pulling weeds up to the roots. The goal is that plant roots are not disturbed and do not become hosts for vectors. If not controlled, it can interfere with plant growth, competition for nutrient absorption, and increase soil moisture which results in attacks by soil-borne pathogens. Pest control is carried out chemically before crossing the threshold using insecticides with the active ingredients of carbofuran and fungicide with active ingredient dimethomorph with a dose of $10 \mathrm{~mL}-1$ each. After the experimental unit is completed, observations are made to support the measurement of parameters during the biostimulation process.

\section{RESULTS AND DISCUSSION}

\section{The Population of Azospirillum sp.}

Aspects of soil fertility are characterized by good soil biological properties. One of the important elements of the biological properties of soil is the population of bacteria contained in it.The microbial population is an increase in the quantity of cell mass through the formation of new cells. The process of bacterial growth depends on the ability of cells to form new protoplasm from nutrients available in the environment.The activity of organisms in the soil will also affect plant growth which will ultimately determine the productivity of the land in which they live(Widyati, 2013).

Azospirillum sp. is a species of rhizobacteria known as N2-fixer diazotrophs, which convert dinitrogen to ammonium by electron reduction and protonation of dinitrogen gas. Based on Table 2. it is known that the population of Azospirillum sp. does not show a significantly different effect in each treatment at 0 DAP (Day After Planting), but tends to increase in the addition of straw compost plus and 1 fertilizer $\mathrm{N}, \mathrm{P}, \mathrm{K}$ recommended dose on non-soil saline $(0$ $\mathrm{dS} / \mathrm{m})$ with a total population of $(7.9 \times 107 \mathrm{CFUg}-1)$. The population of Azospirillum sp. The best in non-saline soil $(0 \mathrm{dS} / \mathrm{m})$ was found in straw compost plus $+3 / 4$ fertilizer $\mathrm{N}, \mathrm{P}, \mathrm{K}$ recommended dose of $(16.32 \times 108 \mathrm{CFUg}-1)$. This proves that the added microbes are able to stimulate and increase the growth of other bacteria around the roots so that it is better than control. An interesting thing happened to the population of Azospirillum sp. in saline soil (4 $\mathrm{dS} / \mathrm{m})$, which showed that the effect was not significantly different in each treatment, but tended to increase in the treatmentstraw compost +1 dose of $\mathrm{N}, \mathrm{P}, \mathrm{K}$ fertilizer $(13.91 \mathrm{x} 108 \mathrm{CFUg}-1)$.

Table 2. Microbial Population at 0 DAP and 45 DAP on Chili Planting Media after Giving Straw Compost and N, P, K Fertilizer.

\begin{tabular}{|c|c|c|c|}
\hline \multirow[t]{2}{*}{ Code } & \multirow[t]{2}{*}{ Treatment } & $\left(10^{7}\right) \mathrm{CFUg}^{-1}$ & rillum $\mathrm{sp}$ \\
\hline & & 0 DAP & $45 \mathrm{DAP}$ \\
\hline $\mathrm{A}$ & & $1.03 \mathrm{a}$ & $6.12 \mathrm{~d}$ \\
\hline
\end{tabular}


Vol. 06, No. 04; 2021

ISSN: $2456-8643$
B Compost Straw +1 fertilizer N, P, K recommended dose $(0 \mathrm{dS} / \mathrm{m})$
$1.11 \mathrm{a}$
$6.35 \mathrm{~d}$
C Compost Straw $+3 / 4$ fertilizer N, P, K recommended dose $(0 \mathrm{dS} / \mathrm{m})$
$2.22 \mathrm{a}$
$6.82 \mathrm{~d}$
D Compost Straw $+1 / 2$ fertilizer N, P, K recommended dose $(0 \mathrm{dS} / \mathrm{m})$
E Compost Straw Plus+1 fertilizer N,P,K recommended dose $(0 \mathrm{dS} / \mathrm{m})$
F Compost Straw Plus + 3/4 fertilizer N,P,K recommended dose $(0 \mathrm{dS} / \mathrm{m})$
G Compost Straw Plus $+1 \frac{1}{2}$ fertilizer N,P,K recommended dose $(0 \mathrm{dS} / \mathrm{m})$
$\mathrm{H} \quad$ Control $(4 \mathrm{dS} / \mathrm{m})$
$3.35 \mathrm{a}$
$8.01 \mathrm{~cd}$
I Compost Straw +1 fertilizer N, P, K recommended dose $(4 \mathrm{dS} / \mathrm{m})$
J Compost Straw $+3 / 4$ fertilizer N, P, K recommended dose $(4 \mathrm{dS} / \mathrm{m})$
K Compost Straw $+1 / 2$ fertilizer N, P, K recommended dose $(4 \mathrm{dS} / \mathrm{m})$
L Compost Straw Plus +1 fertilizer N, P, $\mathrm{K}$ recommended dose $(4 \mathrm{dS} / \mathrm{m})$
M Compost Straw Plus + 3/4 fertilizer N, P, $\mathrm{K}$ recommended dose $(4 \mathrm{dS} / \mathrm{m})$
N Compost Straw Plus $+1 / 2$ fertilizer N, P, $\mathrm{K}$ recommended dose $(4 \mathrm{dS} / \mathrm{m})$

Remarks: Means followed by the same letter on the line indicate no significant differences based on Duncan's Multiple Range Test at $p<0.05$ 
Based on research resultsAkyol, et al.(2019), environmental conditions, soil type, agricultural practices carried out, and the history of the land in the previous planting period are factors that affect the bacterial population in the root area. In addition, the application of bacteria into the soil itself has different effects on the population of indigenous bacteria, including increasing the population of bacteria in the soil, inhibiting the growth of bacteria in the soil, or even having no effect on the existing bacterial population(Mącik, et al., 2020).

\section{N-Total}

Nitrogen is an essential nutrient for plants that is needed in large amounts. The presence of $\mathrm{N}$ in the soil is very mobile so that it is easily lost from the soil through leaching or evaporation.

Table 3. Soil N-Total Content at 45 DAP on Chili Planting Media after Giving Straw Compost and N,P,K Fertilizer

\begin{tabular}{|c|c|c|}
\hline \multirow{2}{*}{ Code } & \multirow{2}{*}{ Treatment } & N-Total (\%) \\
\hline & & $45 \mathrm{HST}$ \\
\hline A & Control $(0 \mathrm{dS} / \mathrm{m})$ & $0,26 \mathrm{a}$ \\
\hline B & $\begin{array}{l}\text { Compost Straw }+1 \text { fertilizer N, P, K } \\
\text { recommended dose }(0 \mathrm{dS} / \mathrm{m})\end{array}$ & $0,23 \mathrm{a}$ \\
\hline $\mathrm{C}$ & $\begin{array}{l}\text { Compost Straw }+3 / 4 \text { fertilizer N, P, K } \\
\text { recommended dose }(0 \mathrm{dS} / \mathrm{m})\end{array}$ & $0,27 \mathrm{a}$ \\
\hline D & $\begin{array}{l}\text { Compost Straw }+1 / 2 \text { fertilizer } N, P, K \\
\text { recommended dose }(0 \mathrm{dS} / \mathrm{m})\end{array}$ & $0,22 \mathrm{a}$ \\
\hline E & $\begin{array}{l}\text { Compost Straw Plus }+1 \text { fertilizer N,P,K } \\
\text { recommended dose }(0 \mathrm{dS} / \mathrm{m})\end{array}$ & $0,24 \mathrm{a}$ \\
\hline F & $\begin{array}{l}\text { Compost Straw Plus }+3 / 4 \text { fertilizer } \\
\mathrm{N}, \mathrm{P}, \mathrm{K} \text { recommended dose }(0 \mathrm{dS} / \mathrm{m})\end{array}$ & $0,25 \mathrm{a}$ \\
\hline G & $\begin{array}{l}\text { Compost Straw Plus }+1 / 2 \text { fertilizer } \\
\text { N,P,K recommended dose }(0 \mathrm{dS} / \mathrm{m})\end{array}$ & $0,22 \mathrm{a}$ \\
\hline $\mathrm{H}$ & Control (4 dS/m) & $0,21 \mathrm{a}$ \\
\hline
\end{tabular}


I Compost Straw +1 fertilizer N, P, K recommended dose $(4 \mathrm{dS} / \mathrm{m})$

$0,31 \mathrm{a}$

J Compost Straw $+3 / 4$ fertilizer N, P, K recommended dose $(4 \mathrm{dS} / \mathrm{m})$ $0,30 \mathrm{a}$

K Compost Straw $+1 / 2$ fertilizer N, P, K recommended dose $(4 \mathrm{dS} / \mathrm{m})$

L Compost Straw Plus +1 fertilizer N, P, $\mathrm{K}$ recommended dose $(4 \mathrm{dS} / \mathrm{m})$ $0,34 \mathrm{a}$

M Compost Straw Plus $+3 / 4$ fertilizer N, P, $\mathrm{K}$ recommended dose $(4 \mathrm{dS} / \mathrm{m})$ $0,21 \mathrm{a}$

$\mathrm{N} \quad$ Compost Straw Plus $+1 / 2$ fertilizer N, P, $\mathrm{K}$ recommended dose $(4 \mathrm{dS} / \mathrm{m})$
$0,22 \mathrm{a}$

Remarks: Means followed by the same letter on the line indicate no significant differences based on Duncan's Multiple Range Test at $\mathrm{p}<0.05$

Based on the results of the N-Total (Table 3), it was shown that the addition of straw compost plus and several doses of N,P,K fertilizer gave no significant effect on both saline $(4 \mathrm{dS} / \mathrm{m})$ and non-saline $(0 \mathrm{dS} / \mathrm{m})$ soils. $\mathrm{m})$, but tends to increase compared to the initial soil analysis containing N-Total $(0.18 \%)$.Straw compost plus +1 fertilizer N, P, K recommended dose (4 $\mathrm{dS} / \mathrm{m})$ tend to be able to increase $\mathrm{N}$-total compared to the control treatment $(0 \mathrm{dS} / \mathrm{m})$. according toDewi and Setiawati (2017), the nitrogen content is influenced by the amount of $\mathrm{N}$ input into the soil, as well as the amount of $\mathrm{N}$ loss from the soil.

Azospirillum sp. are heterotrophic bacteria, so their performance in producing $\mathrm{N}$ depends on the energy source (C-organic) in the soil. The bacteria applied also need to compete with indigenous bacteria for energy sources(Setiawati et al, 2014). Therefore, the application of biostimulants has a role in increasing the $\mathrm{N}$-total (Table 3), but in this study it was not enough to provide a significant difference in increasing the $\mathrm{N}$-total content of the soil.

Climatic conditions play a role in influencing the total $\mathrm{N}$ content of the soil. Conditions of high air temperature and low rainfall allow the process of evaporation and the formation of a lot of water vapor(Hermawan and Komalaningsih, 2010). The high evaporation process has a role in the loss of Nitrogen in the soil(Tando, 2018). Nutrient $\mathrm{N}$ available in the form of NO3- cannot be bound by the soil, so it can be easily carried away by percolation flows to the ground water surface(Sholehati and Setiawati, 2020). This is why the total N content of the soil is not significantly different in each treatment, because it is influenced by climatic conditions that are not suitable for chili plant growth during the vegetative phase. 
Vol. 06, No. 04; 2021

ISSN: $2456-8643$

\section{Fruit set}

Fruit set is an ovary that will become a perfect fruit.Based on Table 4. shows that fruit set. Plants have an inverse relationship to the parameters of the number of flowers and the number of fruit planted. Straw compost $+1 / 2$ fertilizer N,P,K recommended dose $(4 \mathrm{dS} / \mathrm{m})$ is the treatment that has the highest number of flowers compared to with all treatments (18 flowers) and (15 fruits), except for the treatment of straw compost plus $+3 / 4$ application of recommended dose of N,P,K fertilizer $(0 \mathrm{dS} / \mathrm{m})$ which had the number of flowers and fruit as much as (17 flowers) and (15 fruit). The inhibition of the rate of cell division due to salt stress and without the addition of nutrients will stimulate the plant to go to the reproductive phase and form flowers due to the photosynthesis produced is focused on the reproductive organs so that plants can flower faster[19].

Azospirillum sp. is a type of nitrogen fixing bacteria that is able to supply nitrogen needs by fixing free $\mathrm{N} 2$ from the air with the help of the nitrogenase enzyme and converting it into available $\mathrm{N}$ elements. The effectiveness of nitrogenase enzyme activity in fixing nitrogen varies from one isolate to another(Nugraha et al. 2014). This can be seen from the growth of isolates on media without nitrogen where there are isolates that are able to grow with thick colonies, but there are isolates that grow thin colonies. Azospirillum sp. is a non-symbiotic bacteria that is able to associate with plants. In addition, these bacteria are also able to remodel organic materials such as cellulose, amylose, and organic matter containing a number of fats and proteins in the soil so as to increase the stability of soil aggregates(Nurosid, 2008). The difference in fruit set is very clear between saline soil $(4 \mathrm{dS} / \mathrm{m})$ and non-saline soil $(0 \mathrm{dS} / \mathrm{m})$, while the average number of flowers on saline soil grows more than on non-saline soil, however, on saline soil many flowers fall. and does not form ovules.

The interesting thing is seen in the treatmentstraw compost +1 recommended dose of N,P,K fertilizer $(4 \mathrm{dS} / \mathrm{m})$ which gave an effect that was not significantly different from straw compost plus $+3 / 4$ recommended dose of $\mathrm{N}, \mathrm{P}, \mathrm{K}$ fertilizer $(0 \mathrm{dS} / \mathrm{m})$ with each fruit sets of $(87.63 \%)$ and $(88.3 \%)$.

Table 4. Number of Flowers, Fruits, andChili Fruit Set after Giving Straw Compost and $\mathbf{N}, \mathbf{P}, \mathbf{K}$ Fertilizer

\begin{tabular}{|c|c|c|c|c|}
\hline \multirow{3}{*}{ Code } & \multirow{3}{*}{ Treatment } & \multicolumn{3}{|c|}{ Fruit Set $(\%)$} \\
\hline & & & & \\
\hline & & Flower (pcs) & Fruit (pcs) & Fruitset (\%) \\
\hline $\mathrm{A}$ & Control (0 dS/m) & $13 \mathrm{~d}$ & $8 \mathrm{fgh}$ & $59 \mathrm{j}$ \\
\hline B & $\begin{array}{l}\text { Compost Straw }+1 \text { fertilizer } N, P, K \\
\text { recommended dose }(0 \mathrm{dS} / \mathrm{m})\end{array}$ & $13 \mathrm{~d}$ & 8 efg & $62 \mathrm{i}$ \\
\hline
\end{tabular}




\begin{tabular}{|c|c|c|c|c|}
\hline $\mathrm{C}$ & $\begin{array}{l}\text { Compost Straw + 3/4 fertilizer N, P, K } \\
\text { recommended dose }(0 \mathrm{dS} / \mathrm{m})\end{array}$ & $11 \mathrm{e}$ & $7 \mathrm{gh}$ & $63 \mathrm{~h}$ \\
\hline $\mathrm{D}$ & $\begin{array}{l}\text { Compost Straw }+1 / 2 \text { fertilizer } N, P, K \\
\text { recommended dose }(0 \mathrm{dS} / \mathrm{m})\end{array}$ & $9 \mathrm{f}$ & $6 \mathrm{~h}$ & $68 \mathrm{~g}$ \\
\hline $\mathrm{E}$ & $\begin{array}{l}\text { Compost Straw Plus }+1 \text { fertilizer } \\
\mathrm{N}, \mathrm{P}, \mathrm{K} \text { recommended dose }(0 \mathrm{dS} / \mathrm{m})\end{array}$ & $11 \mathrm{e}$ & $10 \mathrm{~cd}$ & $91 \mathrm{a}$ \\
\hline $\mathrm{F}$ & $\begin{array}{l}\text { Compost Straw Plus }+3 / 4 \text { fertilizer } \\
\text { N,P,K recommended dose }(0 \mathrm{dS} / \mathrm{m})\end{array}$ & $17 \mathrm{ab}$ & $15 \mathrm{a}$ & $88 \mathrm{~b}$ \\
\hline $\mathrm{G}$ & $\begin{array}{l}\text { Compost Straw Plus }+1 / 2 \text { fertilizer } \\
\mathrm{N}, \mathrm{P}, \mathrm{K} \text { recommended dose }(0 \mathrm{dS} / \mathrm{m})\end{array}$ & $12 \mathrm{de}$ & 9.6 cde & $83 \mathrm{~cd}$ \\
\hline $\mathrm{H}$ & Control (4 dS/m) & $16 \mathrm{bc}$ & $13 \mathrm{~b}$ & $81 \mathrm{~d}$ \\
\hline I & $\begin{array}{l}\text { Compost Straw }+1 \text { fertilizer N, P, K } \\
\text { recommended dose }(4 \mathrm{dS} / \mathrm{m})\end{array}$ & $15 \mathrm{c}$ & $13 \mathrm{~b}$ & $88 \mathrm{~b}$ \\
\hline $\mathbf{J}$ & $\begin{array}{l}\text { Compost Straw }+3 / 4 \text { fertilizer } N, P, K \\
\text { recommended dose }(4 \mathrm{dS} / \mathrm{m})\end{array}$ & $13 \mathrm{~d}$ & $11 \mathrm{c}$ & $84 \mathrm{c}$ \\
\hline $\mathrm{K}$ & $\begin{array}{l}\text { Compost Straw }+1 / 2 \text { fertilizer N, P, K } \\
\text { recommended dose }(4 \mathrm{dS} / \mathrm{m})\end{array}$ & $18 \mathrm{a}$ & $15 \mathrm{a}$ & $84 \mathrm{c}$ \\
\hline $\mathrm{L}$ & $\begin{array}{l}\text { Compost Straw Plus }+1 \text { fertilizer N, } \\
\text { P, K recommended dose }(4 \mathrm{dS} / \mathrm{m})\end{array}$ & $12 \mathrm{de}$ & $9.6 \mathrm{cde}$ & $83 \mathrm{~cd}$ \\
\hline M & $\begin{array}{l}\text { Compost Straw Plus }+3 / 4 \text { fertilizer N, } \\
P, K \text { recommended dose }(4 \mathrm{dS} / \mathrm{m})\end{array}$ & $13 \mathrm{~d}$ & $10 \mathrm{~cd}$ & $77 \mathrm{e}$ \\
\hline $\mathrm{N}$ & $\begin{array}{l}\text { Compost Straw Plus }+1 / 2 \text { fertilizer N, } \\
P, K \text { recommended dose }(4 \mathrm{dS} / \mathrm{m})\end{array}$ & $12 \mathrm{de}$ & $8.6 \mathrm{def}$ & $74 \mathrm{f}$ \\
\hline
\end{tabular}

Remarks: Means followed by the same letter on the line indicate no significant differences based on Duncan's Multiple Range Test at $\mathrm{p}<0.05$

This is because when the soil is stressed by saline, plants will produce the ACC Deaminase enzyme which plays a role in reducing stress conditions in plants caused by excessive ethylene gas production(Karthikeyan et al., 2012). Ethylene hormone has a function to accelerate 
germination, root development, flowering, and fruit ripening(Noren et al., 2012).This enzyme can also cope with plant conditions in environments with high salinity levels.

The mechanism carried out by this enzyme can be direct or indirect. The formation of the ACC Deaminase enzyme is stimulated by the IAA hormone. If the ethylene gas produced is very high, it will inhibit the elongation of new roots. Azospirillum sp. plays a role in regulating the mechanism in reducing the concentration of ethylene. In the process, the ACC formed will come out of the roots which are further remodeled by biostimulant agents into ammonia and ketobutyrate. The source of $\mathrm{N}$ is obtained from the hydrolysis of ACC, with this process it can reduce the negative effect of ethylene. According toWang et al., (2000), the mechanism of biostimulants in producing the ACC Deaminase enzyme indirectly is to suppress disease in tomato and potato plants.

In contrast to nitrogen nutrients, phosphorus nutrients have a direct role in the growth of the generative components of red chili plants. Phosphorus plays a role in increasing metabolite activity and plant physiological processes during the chili growth phase(Hardjowigeno, 2010), formation of flowers, fruits, and seeds; accelerate ripening; and store and transfer energy. In this experiment, the application of rice straw compost with biostimulants and a single fertilizer (SP36) containing $36 \% \mathrm{P} 2 \mathrm{O} 5$ had a positive role in the yield of chili plants.

The dynamic environment of the rhizosphere and rich in energy sources from organic compounds released by plant roots is a habitat for biostimulants that act as PGPR. Chili root exudates contain the amino acid tryptophan, glucuronic acid, and carbohydrates such as arabinose, mannose, galactose, glucose, and xylose which are further converted into IAA by biostimulants. The IAA released by the microbial consortium is utilized by plants for the root elongation process and stimulates the formation of new roots through the ACC-deaminase cycle. In the ACC-deaminase cycle, IAA reacts with S-adenosylmethionine (SAM) to form 1aminocyclopropane-1-carboxylate (ACC) and the process of SAM formation is facilitated by the enzyme ACC synthase. Furthermore, ACC formed in plants will be utilized by plants and microbes (Feng et al., 2006).

The process of forming ethylene comes from the ACC oxidation process which is facilitated by ACC oxidase. Ethylene formed is used by plants for the root elongation process. Meanwhile, ACC is also used by biostimulant agents for its metabolic processes. Azospirillum sp., was able to convert ACC into ammonia and -ketobutyrate and this process was facilitated by the ACCdeaminase enzyme produced by the microbial consortium. The use of ACC by bacteria is very beneficial for plants, because if the concentration of ACC is too high, it will result in higher ethylene concentrations. It is known that ethylene is toxic to plants in high concentrations. Biostimulants that have the ACC-deaminase enzyme will limit the production of ethylene so that damage to plant tissue can be avoided(Cimmino et al., 2006).

\section{CONCLUSION}

The population of Azospirillumsp. The best on non-saline soil was found in the treatment of straw compost plus $+3 / 4$ fertilizer N,P,K dose with a population of $16.32 \times 108 \mathrm{CFUg}-1$, while in saline soil $(4 \mathrm{dS} / \mathrm{m})$ it was found in the treatment of straw compost +1 dose of N,P,K fertilizer 
(13.91 x $108 \mathrm{CFUg}-1)$. N-total soil gave no significant effect on both saline (4 dS/m) and nonsaline $(0 \mathrm{dS} / \mathrm{m})$ soils, however, the treatment of straw compost plus +1 fertilizer $\mathrm{N}, \mathrm{P}, \mathrm{K}$ at the recommended dose $(4 \mathrm{dS} / \mathrm{m})$ tends to increase compared to the initial soil analysis which contains only $(0.18 \%)$. Straw compost plus the addition of 1 recommended dose of N,P,K fertilizer $(0 \mathrm{dS} / \mathrm{m})$ can maintain flowers with the highest percentage of fruit set $(90.86 \%)$.

\section{ACKNOWLEDGMENTS}

The author would like to thank Padjadjaran University for funding this research through the Unpad Lecturer Competency Research (RKDU) 2020 scheme.

\section{REFERENCES}

Abdel-Fattah, M,K. 2012. Role of gypsum and compost in reclaiming saline-sodic soils. IOSR Journal of Agriculture and Veterinary Science (IOSR-JAVS), 1:30-38.

Ahmad, F., I. Ahmad, and M,S, Khan. 2008. Screening of free-living rhizospheric bacteria for their multiple plant growth promoting activities. Microbiology Research. 168:173-181.

Akyol, T, Y., Rieko, N., Hideki, H., Hayato, M., Takumi, S., Takae, S., Ayako, F., Takashi, S., Shigenobu, Y., Keitaro, T., Masanori, S., Tatsuhiro, E., Shusei, S. 2019. Impact of introduction of arbuscular mycorrhizal fungi on the root microbial community in agricultural fields. Microbes Environ, 34, pp. 23-32.

Bonjour, JP 1991. Biotin. In Handbook of Vitamins (LJ Machlin, ed.), p. 393-427. Marcel Dekker, Inc., New York, NY, USA.

Cimmino A., A. Andolfi, G. Marchi, G. Surico, and A. Evindente. 2006. Phytohormone production by strain Pantoea agglomerans from knots on olive plants caused by Pseudomonas savastanoi pv. savastanoi. Phytopathol.mediterr., 45:247-252.

Dewi, K,A., and Setiawati, M,R 2017. Effect of Endophytic Biofertilizer with Azolla pinnata on N Uptake, N-Total Soil and Dry Weight of Rice (Oryza sativa L.) in saline soil. agrology. 6(2) : 54-60.

Feng, Y., D. Shen, and Song, W. 2006. Rice endophyte Pantoea agglomerans YS19 promotes host plant growth and effects allocations of host photosynthates. Journal of Applied Microbiology, 100: 938-945.

Gamalero, E., Lingua, G., Berta, G., and Glick BR 2009. Beneficial role of plant growth promoting bacteria and arbuscular mycorrhizal fungi on plant responses to heavy metal stress. Can J Microbiol 55 (5):501-514.

Gharib, FA, LA Moussa and ON Massoud. 2008. Effect of compost and bio-fertilizers on growth, yield and essential oil of sweet marjoram (Majorana hortensis) plant. int. J. Agri. Biol., 10:381-387.

Hardjowigeno, S., 2010. Soil Science. 7th edition. Bogor: Pressindo Academics. 
Hermawan, E. and Komalaningsih, K., 2010. The characteristics of the Indian ocean dipole mode in the Indian Ocean are related to the behavior of rainfall in the West Sumatra region based on mother wavelet analysis. Journal of Aerospace Science, 5(2), pp. 109-129.

Indriani, F, N., Hindersah, R., and Suryatmana, P. 2017. N-Total, N Uptake, and Growth of Peanut (Arachis hypogaea L.) Due to Azotobacter and Organic Matter Inoculation in Gold Mine Tailings Buru Island, Maluku . Soilrens, 15(2), 33-40.

Karthikeyan, B., Joe, MM, Islam, MR, Sa, T. 2012. ACC deaminase containing diazotrophic endophytic bacteria ameliorate salt stress in Catharanthus roseus through reduced ethylene levels and induction of antioxidative defense systems. Symbiosis, 56:77 86.

Lestari, P. Susilowati, DN and Riyanti, EI 2007. Effect of the hormone indole acetic acid produced by Azospirillum sp. on rice root development. J. Agro Biogen 3(2) : 66-72.

Lugtenberg, B. and F. Kamilova. 2009. Plant Growth Promoting Rhizobacteria. Ann. Rev. of Microbes. 63:541-556.

Mącik, M., Gryta, A. and Frąc, M., 2020. Biofertilizers in agriculture: an overview on concepts, strategies and effects on soil microorganisms. Advances in Agronomy, Volume 162, pp. 32-87.

Mohammadi, N. k., Pankhaniya, R., Patel, K. and Rahmani, N., 2017. Effect of various levels of inorganic fertilizer and vermicompost with and without bio-fertilizer on growth, yield attributes and yield of sweet corn ( Zea mays L. saccharata). International Journal of Multidisciplinary Research and Development, 4(5), pp. 114-117.

Munns, R. and Tester, M. 2008. Mechanisms of Salinity Tolerance. annu. Rev. Biol Plant. 59:651-681.

Noren, S., Ali, B., Hasnain, S. 2012. Growth promotion of Vigna mungo (L.) by Pseudomonas spp. exhibiting auxin production and ACCdeaminaseactivity. Annals of Microbiology., 62: 411 7.

Nugraha, R., A. Asdyati, Suharjono. 2014. Exploration of potential cellulolytic bacteria as biofertilizer agents from apple plantation soil in Batu City, East Java. Journal of Biotropics. 2:59-163.

Nurosid., Oedjijono, and Puji, L. 2008. Ability of Azospirillum sp. JG3 in Produce Lipase in Mixed Medium Bran with Different Incubation Time. Purwokerto: Faculty of Biology Unsoed.

Pliego, C., Kamilova, F., Lugtenberg, B. 2011. Plant growth-promoting bacteria: fundamentals and exploitation. In: Maheshwari DK (ed) Bacteria in agrobiology: crop ecosystems. Springer, Berlin, pp. 295-343.

Prawiranata W., S. Harran and P. Tjndronegoro. 1992. Fundamentals of plant physiology. Faculty of Mathematics and Natural Sciences. Bogor Agricultural University. 247 p. 
Vol. 06, No. 04; 2021

ISSN: $2456-8643$

Setiawati, M, R., Suryatmana, P., Hindersah, R., Fitriatin, B, N., and Herdiyantoro, D. 2014. Characterization of Phosphate Solubilizing Bacterial Isolates to Increase PAvailability in Liquid Culture Media of Corn Plants (Zea mays L. .). Journal of Biological and Physical Sciences, 16(1): 38-42.

Sholehati, K, and Setiawati, T, C. 2020. Effect of water hyacinth bokashi fertilization and Azolla liquid organic fertilizer on C-organic content, N-total soil, and nitrogen nutrient uptake of soybean (Glycine max (L.) Merill.) On Sandy Land. Agricultural Scientific Periodic, 3(1), pp. 33-35.

[USDA] United States Department of Agriculture . 2010. Plants for Saline to Sodic Soil Condition. TN Plant Materials No. 9A. Natural Resources Conservation Service Boise, Idaho, Salt Lake City, Utah.

Wang, C, E, Knill, B, R, Glick, and Defago, D. 2000. Effect of transferring 1aminocyclopropane-1-carboxylic acid (ACC) deaminase gene into Pseudomonas fluorescens strain $\mathrm{CHA0}$ and its gacA derivative CHA96 on their growth -promoting and disease-suppressive capacities. can. J. Microbiol. 46: 898-907.

Widyati, E. 2013. The Importance of Functional Diversity of Soil Organisms on Land Productivity Research and Development Center for Forest Productivity Improvement, Forestry Research and Development Campus, Bogor.

Zahran, H, H, Ahmad, M, S, and Afkar, E, A. 1995. Isolation and characterization of nitrogenfixing moderate halophilic bacteria from saline soils of Egypt. Journal of Basic Microbiology, 35(4), 269-275. 